\title{
MONIKA CZERW
}

Akademia im. Jana Dtugosza w Częstochowie

\section{RECENZJA KSIĄŻKI PREORIENTACJA I ORIENTACJA \\ ZAWODOWA W EDUKACJI DANIELA KUKLI, WYD. WNP UKSW, SERIA LABOR, WARSZAWA 2010}

Dostępna od niedawna książka Preorientacja i orientacja zawodo$\boldsymbol{w a} \boldsymbol{w}$ edukacji stanowi kolejną pozycję tego autora ukazującą się w serii wydawniczej LABOR wydawanej przez Katedrę Pedagogiki Pracy i Pedagogiki Społecznej Uniwersytetu Kardynała Stefana Wyszyńskiego w Warszawie, uzupełniając wydawniczą lukę wśród pozycji z tego zakresu.

Jak podkreśla recenzent: „,praca stanowi oryginalne, a zarazem nowatorskie, spojrzenie na tak istotną kwestię, jaką jest planowanie przyszłości edukacyjno-zawodowej przez młodzież. Publikacja tym bardziej wydaje się ważna i cenna na rynku wydawniczym, gdyż brak jest pozycji, które przedstawiałyby w sposób tak przejrzysty, a zarazem syntetyczny, role kształcenia młodego człowieka i wpływu całościowego procesu edukacji na klarownie się jego planów związanych z przyszłością edukacyjno-zawodowa. Autor dokonał wnikliwej analizy interpretacyjnej materiałów źródłowych, literatury przedmiotu, czego pokłosiem jest niniejsze opracowanie. Jest to nowe spojrzenie na kwestie ,edukacji do pracy" w zglobalizowanym świecie. Przedstawione w opracowaniu zagadnienia z zakresu przygotowania kadry pedagogicznej, ale i również jej roli w procesie kształtowania się zainteresowań i aspiracji młodego człowieka w kwestii planów edukacyjno-zawodowych jest ważne i potrzebne we współczesnym systemie edukacji” (z recenzji dr hab. Urszuli Ordon, prof. AJD). 
Domeną podzielonej VII rozdziałów tworzących spójną całość książki jest jasność i rzetelność przekazu, dzięki czemu niniejsza pozycja bez obaw posłużyć może za narzędzie pomocnicze w pracy doradców zawodowych, nauczycieli czy pedagogów. Ponadto stanowić będzie ciekawą lekturę dla zainteresowanych przyszłością swoich dzieci rodziców. Zakłada się również, iż w gronie jej adresatów znajdą się studenci pragnący w toku studiów oprzeć swoją wiedzę na trwałych podbudowach.

Już we wstępie składającej się z 164 stron pozycji autor uzasadnia i obrazowo prezentuje przyświecający mu cel, jakim jest „zwrócenie uwagi na ważność i ważkość wszelkich procesów mających wpływ na wybory edukacyjno-zawodowe młodzieży, ale i na kształtowanie się życiowych wyborów".

W prezentowanej książce autor uświadamia nam rolę elementów wspomagających podejmowanie przez młodzież decyzji edukacyjnozawodowych. Podkreśla znaczenie rodzinnych oddziaływań, istotny wpływ wykwalifikowanego i kompetentnego pedagoga szkolnego oraz doradcy zawodowego, nawiązując przy tym do postępującego procesu globalizacji. Autor nie zapomina również o roli wybranych instytucji resortu edukacji wywierających mniej lub bardziej bezpośrednio wpływ na dokonywanie tak znaczących w życiu młodego człowieka wyborów oraz najważniejszych prawnych unormowań regulujących prowadzenie poradnictwa zawodowego w szkołach. Interesującym zdaje się być fakt, iż - ze względu na precyzję i jasność przekazów w niej zwartych - adresowana jest nie tylko do doradców zawodowych, nauczycieli czy pedagogów, ale również zainteresowanych przyszłością swoich dzieci rodziców. Ponadto zakłada się, iż w gronie jej odbiorców znajdą się studenci pragnący $\mathrm{w}$ toku studiów oprzeć swoją wiedzę na solidnych podwalinach.

„Kształt polskiej szkoły jest tym zagadnieniem, które decyduje o losie dzieci i młodzieży. Idąc dalej, kształtuje obraz społeczeństwa obywatelskiego i społeczeństwa domagającego się permanentnej edukacji. (...) Praca jest tym obszarem bytowania człowieka, gdzie dokonuje się weryfikacji edukacji i wychowania. To w jej procesie człowiek odsłania całokształt swego potencjału intelektualnego i kompetencyjnego. 
Wychodząc naprzeciw ważności tegoż zagadnienia reforma szkolnictwa wskazuje na potrzebę aktywnej obecności doradcy zawodowego w szkole i innych placówkach oświatowych.

Przeto z uznaniem należy przyjąć tę publikację. Jest to rzetelne kompendium wiedzy o celach i funkcjach doradcy zawodowego; jego relacyjności do przedszkola, szkoły czy poradni psychologiczno-pedagogicznej. Czymś co scala te tereny kształcenia dzieci i młodzieży jest powiązanie $\mathrm{z}$ fundamentalnym środowiskiem życia, to jest rodzina, w którą to wpisuje się działalność doradcy zawodowego w funkcji pomocniczości i współzależności. Te obszary działań doradcy zawodowego obligują go do własnej tożsamości osobowościowo-zawodowej. Przeto Autor ukazuje jakimi cechami powinien charakteryzować się doradca zawodowy. Suponuje tym samym potrzebę doradców kompetencyjnych" - pisze w swej recenzji dr hab. Adam Solak, prof. UKSW.

Publikacja ta umożliwia stworzenie logicznego obrazu często trudnego procesu, jakim jest planowanie przyszłości edukacyjno-zawodowej. Jak podkreśla dr hab. Adam Solak, prof. UKSW, „dzieło to jest rzetelnym materiałem dydaktycznym i kompendialnym. Wczytując się w publikację należy stwierdzić, (...) że stanowi bogaty materiał nie tylko dla doradców zawodowych, ale także dla wszystkich nauczycieli, którym zależy na właściwym formowaniu człowieka dojrzałego, posiadającego zadowolenie $\mathrm{z}$ własnego życia $\mathrm{w}$ świecie ciagle zmieniającym się. Publikacja jest także bogatym materiałem z którego mądrość czerpać mogą studenci w toku studiów, pracodawcy i decydujący o kształcie edukacji. 